\title{
ANALISIS FAKTOR-FAKTOR YANG MEMPENGARUHI PENINGKATAN KUALITAS HIDUP PENDERITA STROKE
}

\author{
Sri Wahyuni \\ Universitas PGRI AdiBuana Surabaya
}

\begin{abstract}
ABSTRAK
Stroke atau gangguan peredaran darah otak (GDPO) merupakan penyakit neuorologik yang sering dijumpai di negara-negara maju maupun berkembang. Analisis diskriptif digunakan untuk mengetahui karakteristik pasien stroke dilihat dari kualitas hidupnya, sedangkan regresi logistik dikotomus digunakan untuk mengetahui faktor terapi yang berpengaruh terhadap kualitas hidup penderita stroke.Dalam analisis deskriptif disimpulkan bahwa dari 151 penderita stroke yang diambil pada bulan Januari sampai dengan Juni tahun 2006 menunjukkan bahwa ada 92 orang $(60,9 \%)$ yang kualitas hidupnya meningkat dari keadaan awal. Sedangkan sisanya 59 orang $(39,1 \%)$ kualitas hidupnya tetap seperti keadaan awal masuk rumah sakit. Kondisi penderita stroke ditinjau dari masalah yang berhubungan dengan terapi obat-obatan menunjukkan bahwa 16 orang $(10,6 \%)$ mengalami masalah ketidaktepatan obat, 31 orang $(20,5 \%)$ mendapatkan ketidaktepatan saat pemberian obat, lama pemberian obat yang tidak tepat sebanyak 31 orang $(20,5 \%)$, 29 orang $(19,2 \%)$ yang gagal mendapatkan obat, hanya ada 4 orang $(2,6 \%)$ yang mengalami interaksi obat, 35 orang $(23,2 \%)$ yang menggunakan tidak sesuai dengan petunjuk yang diberikan. Dengan mengunakan analisis regresi logistik terdapat 4 variabel yang berpengaruh terhadap usaha peningkatan kualitas hidup penderita stroke.
\end{abstract}

Kata Kunci : Stroke, deskriptif, regresi logistik

\section{Pendahuluan}

Stroke atau gangguan peredaran darah otak (GDPO) merupakan penyakit neuorologik yang sering dijumpai di negara-negara maju maupun berkembang.Demikian juga di ruang syaraf Rumah Sakit Umum Dr. Soetomo Surabaya, penderita yang paling banyak dijumpai adalah penderita stroke.Di Amerika Serikat stroke merupakan penyakit penyebab kematian no. 3 setelah jantung. Selain itu stroke merupakan penyakit yang dapat menimbulkan kecacatan yang kronik dan tidak hanya menyerang usia lanjut tetapi juga menimpa usia produktif yaitu usia 40-50 tahun (Gilroy, Murray, dalam Saiful, 1998)

Pengobatan stroke bertujuan untuk mempercepat kesembuhan dan mencegah timbulnya komplikasi yang dapat mengakibatkan kecacatan ataupun kematian. Untuk itu perlu dilakukan penelitian guna mengetahui variabel-variabel yang berpengaruh terhadap kualitas hidup penderita stroke berdasarkan terapi obat-obatan.

\section{Tinjauan Pustaka}

2.1 Analisis Regresi Logistik

Metode regresi merupakan bagian penting dalam analisa data, karena mampu menjelaskan hubungan antara variabel respon dengan satu atau lebih variabel prediktor.Apabila dalam suatu kasus terdapat variabel responnya bersifat kategorikal, baik nominal atau ordinal, maka analisis yang digunakan adalah regresi logistik. Tujuan dari pembentukan model analisis regresi logistik adalah untuk menentukan model terbaik yang dapat menjelaskan hubungan antara sebuah variabel respon dengan satu atau sejumlah variabel prediktor. Untuk variabel respon yang hanya memiliki dua kategori saja yaitu Ya ( $Y=1$ ) dan tidak ( $Y=0$ ) maka variabel respon tersebut akan mengikuti distribusi Bernoulli untuk setiap observasinya.

Fungsi probabilitas Bernoulli tersebut adalah sebagai berikut :

$$
\begin{aligned}
& f(y)=p_{i}^{y_{i}}\left(1-p_{i}\right)^{1-y_{i}} \quad ; y_{i}=0,1 \\
& \text { dimana }: p_{i}=p\left(y_{i}=1\right)
\end{aligned}
$$

Model regresi logistik yang memiliki variabel independent lebih dari satu merupakan kasus regresi logistik multiple. Untuk $p$ variabel independen dinotasikan dengan vektor $X^{\prime}=\left(X_{1}, X_{2}, \ldots, X_{k}\right)$. Sedang probabilitas bersyarat dari responnya ditunjukkan dengan $P(Y=1 / x)=\pi(x)$

Maka model regresi logistiknya adalah :

$$
\pi\left(x_{i}\right)=\frac{\left(\beta_{o}+\beta_{1} x_{1}+\ldots+\beta_{k} x_{k}\right.}{1+\exp \left(\beta_{o}+\beta_{1} x_{1}+\ldots+\beta_{k} x_{k}\right)}
$$

dengan $\mathrm{k}=$ jumlah variabel independen 
Untuk memperoleh fungsi linear, maka dari model pada persamaan di atas dilakukan transformasi, sehingga diperoleh model sebagai berikut :

$$
g\left(x_{i}\right)=\ln \left(\frac{\pi(x)}{1-\pi(x)}\right)=\sum_{j=0}^{k} \beta_{j} x_{j}
$$

\section{Metodologi Penelitian}

\subsection{Pengambilan Data}

Data penelitian diambil dari RSUD Dr. Soetomo Surabaya, yaitu dari bulan Januari 2006 sampai dengan Juni 2006 untuk pasien yang dirawat di ruang saraf A. Jumlah sampel sebanyak 151 yang diambil dari pasien stroke yang dirawat minimal enam hari di rumah sakit tersebut agar diketahui reaksi akibat terapi obatobatan yang diberikan. Di samping itu pasien tersebut dalam keadaan masih hidup ketika keluar dari rumah sakit untuk mengukur keadaan mental dan motoriknya.

\subsection{Variabel Penelitian}

Variabel dalam penelitian ini adalah sebagai berikut :

Variabel dependen : peningkatan kualitas hidup penderita stroke dimana kategorinya adalah meningkat dan tidak meningkat.

Variabel Independen : meliputi variabel faktor risiko stroke dan kriteria kerasionalan penggunaan obat.

- Faktor risiko stroke (kategori ya dan tidak) meliputi :

1. Jenis Kelamin

2. Hipertensi

3. Diabetes mellitus

4. Penyakit jantung

5. Merokok

6. Hiperkolesterolimenia

- Kriteria kerasionalan penggunaan obatFaktor risiko stroke (kategori ya dan tidak) meliputi :

1. Seleksi obat

2. Saat pemberian obat

3. Lama pemberian obat

4. Gagal untuk mendapatkan obat

5. Efek samping obat

6. Penggunaan obat tanpa indikasi khusus (spesifik)

7. Keadaan mental saat masuk rumah sakit

8. Keadaan motorik saat masuk rumah sakit

\subsection{Metode Analisis}

Untuk dapat menjawab tujuan dari penelitian ini maka langkah yang harus dilakukan adalah sebagai berikut :

1. Untuk mengetahui karakteristik pasien stroke dilihat dari kualitas hidupnya maka dibuat analisis deskriptif.

2. Untuk menentukan faktor terapi yang berpengaruh terhadap kualitas hidup penderita stroke maka digunakan regresi logistic dikotomus dengan langkah sebagai berikut :

a. Membuat model regresi univariate untuk masing-masing variabel, agar diketahui peranan masing-masing variabel.

b. Memilih variabel independen yang signifikan $(\mathrm{p}<0,25)$ untuk dimasukkan ke model multivariate

c. Menyusun model multivariate berdasarkan variabel yang signifikan pada model univariate.

d. Memeriksa kemungkinan adanya interaksi antar variabel independen, jika ada interaksi maka model yang terbentuk ditambahkan variabel interaksi tersebut.

e. Untuk mengetahui kemungkinan penderita stroke dalam meningkatkan kualitas hidupnya dilihat dari persamaan regresi logistiknya. 


\section{Analisis Data Dan Pembahasan}

\subsection{Analisis Deskriptif}

Analisis Deskriptif ini memberikan gambaran mengenai kondisi penderita stroke di Rumah Sakit Umum Daerah (RSUD) Dr. Soetomo Surabaya pada ruang syaraf A. Dari 151 penderita stroke yang diambil pada bulan Januari sampai dengan Juni tahun 2006 menunjukkan bahwa ada sebanyak 92 orang (60,9\%) yang kualitas hidupnya meningkat dari keadaan awal. Sedangkan sisanya 59 orang $(39,1 \%)$ kualitas hidupnya tetap seperti keadaan awal masuk rumah sakit.

Penderita stroke jika ditinjau menurut jenis kelaminnya paling banyak berjenis kelamin laki - laki, yaitu sebanyak 88 orang $(58,3 \%)$, sedangkan penderita yang berjenis kelamin perempuan yaitu sebanyak 63 orang $(41,7 \%)$

Dilihat dari masalah yang berhubungan dengan terapi obat - obatan (drug related problem) pada penderita stroke menunjukkan bahwa 16 orang $(10,6 \%)$ mengalami masalah pada ketidaktepatan obat misalnya karena beberapa alasan misalnya faktor kemampuan ekonomi penderita, sedangkan ada banyak 135 orang $(89,4 \%)$ pemberian obatnya sudah tepat. Saat pemberian obat juga penting bagi penderita stroke, dimana ada sebanyak 120 orang $(79,5 \%)$ yang saat pemberian obatnya sudah tepat, tetapi ada sebanyak 31 orang $(20,5 \%)$ yang tidak tepat. Demikian juga halnya dengan lama pemberian obat, sedangkan yang tidak benar sebanyak 31 orang $(20,5 \%)$. Penderita stroke yang tidak mendapatkan ketidaktepatan dalam saat pemberian obat maupun lama pemberiannya hal ini berkaitan dengan kemampuan ekonomi penderita, keterlambatan penderita atau keluarganya membeli obat, keterlambatan datang ke rumah sakit.

Dilihat dari kegagalan mendapatkan obat karena faktor ketidakmampuan ataupun faktor farmakokinetika maka sebagian besar penderita stroke tidak mengalami kesulitan untuk mendapatkan obat hal ini dapat dilihat dari jumlahnya sebesar 122 orang $(80,8 \%)$ yang sukses mendapatkan obat. Sedangkan yang gagal hanya ada 29 orang $(19,2 \%)$. Kalau dilihat dari faktor adanya interaksi obat yang telah diberikan menunjukkan bahwa sebanyak 147 orang $(97,4 \$)$ tidak mengalami interaksi obat, sedangkan sisanya sebanyak 4 orang $(2,6 \%)$ mengalami interaksi obat yang diberikan. Untuk penggunaan obat tanpa indikasi khusus misalnya pemberian vitamin ada sebanyak 35 orang $(23,2 \%)$ yang menggunakan tanpa indikasi khusus, sedangkan 116 orang $(76,8 \%)$ tidak menggunakan obat di luar yang diberikan.

\subsection{Analisis Regresi Logistik}

Analisa regresi logistik digunakan untuk mengetahui faktor-faktor yang menyebabkan peningkatan kualitas hidup penderita stroke dari keadaan awal masuk rumah sakit. Analisis ini meliputi analisis regresi Logistik secara univariabel dan multivariabel. Analisa regresi Logistik univariabel digunakan untuk mengetahui peranan masing-masing variabel terhadap keberhasilan meningkatkan kualitas hidup penderita stroke, di samping itu juga digunakan untuk memilih variabel-variabel yang akan dimasukkan ke model multivariabel.

\subsubsection{Model Univariabel}

Hasil analisis regresi logistik secara univariabel dapat diketahui bahwa variabel - variabel yang signifikan secara univariabel terhadap usaha peningkatan kualitas hidup penderita stroke adalah variabel kesuksesan mendapatkan obat signifikan pada dengan nilai $\mathrm{p}$ sebesar 0,0005, demikian juga untuk variabel saat pemberian obat nilai $p$ sebesar 0,0465. Untuk variabel keadaan mental saat masuk rumah sakit signifikan untuk $\alpha=10 \%$ dengan nilai p sebesar 0,0662. Sedangkan variabel seleksi obat signifikan pada $\alpha=25 \%$. Dimana nilai $p$ untuk variabel seleksi obat sebesar 0,1435 .

\subsubsection{Model Multivariabel}

Pada analisis regresi logistik multivariabel, variabel yang akan dimasukkan adalah variabel yang signifikan secara univariabel. Dengan berpedoman pada $\alpha=25 \%$ maka variabel yang signifikan secara univariabel adalah seleksi obat, gagal atau tidaknya dalam mendapatkan obat dan keadaan mental pada saat masuk rumah sakit. Pembentukan model regresi logistik multivariabel ini dilakukan dengan metode Backward, dan didapatkan model sebagai berikut :

$$
\pi(x)=\frac{\operatorname{Exp}(-1,2720+0,7882 S O(1)+0.9019 S P O(1)+1,7204 G M O(1)-0,2759 I N M E N)}{1+\operatorname{Exp}(-1,2720+0,7882 S O(1)+0,9019 S P O(1)+1,7204 G M O(1)-0,2579 I N M E N}
$$

Dilihat dari nilai odds rasionya dapat diketahui bahwa :

1. Penderita stroke yang mendapatkan obat dengan tepat mempunyai peluang 2 kali lebih besar untuk sukses dalam meningkatkan kualitas hidupnya dari keadaan awal masuk rumah sakit dibandingkan pasien yang tidak mendapatkan obat dengan tepat. 
2. Variabel saat pemberian obat mempunyai nilai odds ratio sebesar 2,4643 , artinya penderita stroke yang tepat pemberian obatnya memiliki peluang sekitar 2,5 kali lebih besar dalam meningkatkan kualitas hidupnya dibandingkan penderita yang tidak tepat saat pemberian obatnya.

3. Untuk variabel gagal mendapatkan obat (GMO), pasien yang sukses mendapatkan obat mempunyai peluang untuk berhasil dalam meningkatkan kualitas hidupnya dari keadaan awal masuk rumah sakit sekitar 5,5 kali lebih besar dibandingkan pasien yang gagal mendapatkan obat. Ini artinya faktur kegagalan mendapatkan obat perlu diperhatikan demi keberhasilan pengobatan yang telah diberikan.

4. Sedangkan untuk pasien yang semakin tinggi keadaan mental penderita stroke pada saat masuk rumah sakit mempunyai peluang untuk berhasil meningkatkan kualitas hidupnya sebesar 0.7726 dibandingkan pasien yang lainnya.

\section{Kesimpulan}

1. Dalam analisis deskriptif dapat disimpulkan bahwa dari 151 penderita stroke yang diambil pada bulan Januari sampai dengan Juni tahun 2006 menunjukkan bahwa ada 92 orang $(60,9 \%)$ yang kualitas hidupnya meningkat dari keadaan awal. Sedangkan sisanya 59 orang $(39,1 \%)$ kualitas hidupnya tetap seperti keadaan awal masuk rumah sakit.

Kondisi penderita stroke jika ditinjau dari masalah yang berhubungan dengan terapi obat-obatan (drug related problem) menunjukkan bahwa 16 orang (10,6\%) mengalami masalah ketidaktepatan obat, 31 orang $(20,5 \%)$ mendapatkan ketidaktepatan saat pemberian obat, lama pemberian obat yang tidak tepat sebanyak 31 orang $(20,5 \%), 29$ orang $(19,2 \%)$ yang gagal mendapatkan obat, hanya ada 4 orang $(2,6 \%)$ yang mengalami interaksi obat, 35 orang $(23,2 \%)$ yang menggunakan tidak sesuai dengan petunjuk yang diberikan.

2. Dengan mengunakan analisis regresi logistik terdapat 4 variabel yang berpengaruh terhadap usaha peningkatan kualitas hidup penderita stroke, yaitu : seleksi obat, saat pemberian obat, gagal mendapatkan obat dan keadaan mental penderita saat masuk rumah sakit.

3. Untuk melihat sejauh mana suatu kategori variabel berpengaruh terhadap kualitas hidupnya dapat dilihat dari nilai odds rationya. Nilai odds ratio untuk variabel seleksi obat sebesar 2,1993, saat pemberian obat sebesar 2,4643, gagal mendapatkan obat sebesar 5,5865 dan 0,7726 untuk keadaan mental penderita stroke pada saat masuk rumah sakit.

\section{Daftar Pustaka}

Fahmeir,L dan Tutz, G. (1994), Multivariate Statistical Modelling Based on Generalized Linier Models, Springer-Verlag.

Hosmer, D. W dan Lemeshow. (2000), Applied Logistik Regression, second edition, John Wiley and Sons. Inc, New York.

Kleinbaum, David G. (1994). Logistic Regression, a self Learning Text.Springer Verlag new york.

Madigan, David. Genkin, Alexander. Lewis, David D dan Fradkin, Dmitry (2005).Bayesian Multinomial Logistic Regression for Author Identification, Rutger university.

Madigan, David. Genkin, Alexander. Lewis, David D dan Fradkin, Dmitry (2005).Bayesian Multinomial Logistic Regression for Author Identification, Rutger university, Amerika Serikat.

Tahir, Muhammad dan Hussain, Zawar. (2000). Comparison of Non Informative Priors for Number of Defects (Poisson) Model. Department of Statistics, Government Degree College, Pindhi Gheb, Pakistan. 